\title{
INOVASI MANAJEMEN PENDIDIKAN DI MADRASAH TSANAWIYAH AR ROSIDIYAH BANDUNG
}

\author{
EDUCATIONAL MANAGEMENT INNOVATION \\ AT MADRASAH TSANAWIYAH AR ROSIDIYAH BANDUNG
}

\author{
Ahmad Husni Hamim \\ e-mail : ahmadhusni@gmail.com \\ Widyaswara Balai Diklat Keagamaan Bandung \\ Ibnu Abdillah Hammam Fauzi \\ e-mail : abuhadad81@gmail.com \\ UIN Sunan Gunung Djati Bandung \\ Qiqi Yuliati Zakiah \\ email : iqiyuliatizaqiah@uisgd.ac.id \\ UIN Sunan Gunung Djati Bandung \\ Mohammad Erihadiana \\ email: mohammaderihadiana@uinsgd.ac.id \\ UIN Sunan Gunung Djati Bandung \\ Asep Munawar \\ email: raihanyasirtaofiq@gmail.com \\ UIN Sunan Gunung Djati Bandung
}

\begin{abstract}
Abstrak
Penelitian ini dilatarbelakangi bahwa derasnya arus informasi, hiburan dan media sosial Penelitian ini bertujuan untuk mengetahui inovasi manajemen pendidikan di MTs Ar Rosidiyyah Bandung. Penelitian ini merupakan penelitian lapangan (field work research) yang meliputi aspek perencanaan, implementasi dan evaluasi. Sumber data dalam penelitian ini adalah kepala madrasah, waka kurikulum, waka sarpras dan beberapa guru. Dalam melakukan pengumpulan data, penulis menggunakan tiga macam teknik, yaitu observasi, wawancara dan dokumentasi. Selanjutnya penulis menganalisis dengan menggunakan model analisis interaktif Milles and Huberman, dengan alur reduksi data, penyusunan data dan penarikan kesimpulan. Hasil penilitian menunjukkan bahwa : Inovasi manajemen Pendidikan di MTs Ar Rosidiyyah Bandung dilakukan dengan mengacu pada tiga tahapan, yaitu: Pertama, Inovasi pada tahap perencanaan yang di dalamnya mencakup proses goal, identifikasi masalah, penunjang dan penghambat, alternatif pemecahan masalah, alternatif pengambilan keputusan, dan evaluasi. Kedua, inovasi pada tahap pelaksanaan yang di dalamnya mencakup proses sosialisasi, poling, dan deseminasi. Ketiga, inovasi pada tahap evaluasi yang di dalamnya mencakup proses identifikasi masalah, membuat skala prioritas masalah, analisis masalah, solusi alternative, dan rencana tindak lanjut.
\end{abstract}


Kata kunci: Inovasi, Manajemen, Pendidikan.

\begin{abstract}
This study aims to determine the innovation of education management at MTs Ar Rosidiyyah Bandung. This research is a field research (field work research) which includes aspects of planning, implementation and evaluation. Sources of data in this study were the head of the madrasa, waka curriculum, waka sarpras and several teachers. In collecting data, the author uses three kinds of techniques, namely observation, interviews and documentation. Furthermore, the authors analyzed using the Milles and Huberman interactive analysis model, with the flow of data reduction, data compilation and drawing conclusions. The results of the research show that: Educational management innovation at MTs Ar Rosidiyyah Bandung is carried out with reference to three stages, namely: First, Innovation at the planning stage which includes the goal process, problem identification, supports and barriers, alternative problem solving, alternative decision making, and evaluation. Second, innovation at the implementation stage which includes the process of socialization, polling, and dissemination. Third, innovation at the evaluation stage which includes the process of identifying problems, making problem priority scales, problem analysis, alternative solutions, and follow-up plans.
\end{abstract}

Keywords: Innovation, Management, Education

Submitted : 09-11-2021 | Accepted: 27-11-2021 | Published : 26-12-2021

\title{
PENDAHULUAN
}

Salah satu permasalahan pendidikan yang dihadapi oleh bangsa Indonesia adalah bagaimana meningkatkan mutu pendidikan yang mampu bersaing di era globalisasi. Dalam konsep 'globalisasi', Michael Hammer dan James Champy menuliskan bahwa ekonomi global berdampak terhadap 3 C, yaitu customer, competition, dan change. Pelanggan menjadi penentu, pesaing makin banyak, dan perubahan menjadi konstan. Tidak banyak orang yang suka akan perubahan, namun walau begitu perubahan tidak bisa dihindarkan. Harus dihadapi. Karena hakikatnya memang seperti itu maka diperlukan satu manajemen perubahan agar proses dan dampak dari perubahan tersebut mengarah pada titik positif (Amiroh, 2014).

Lembaga pendidikan, khususnya lembaga pendidikan Islam harus berperan aktif untuk mewujudkan sistem pendidikan yang menjawab tantangan globalisasi. Namun sistem pendidikan Islam di Indonesia sekarang ini masih dipertanyakan kedudukan dan kompetensi lulusannya, yang kurang mampu bersaing dengan mutu lulusan lembagalembaga lain yang benar- benar sudah memperhatikan masalah pendidikan (Rouf. A., 2016). Maka dari itu lembaga pendidikan Islam harus berbenah dan memperbaik mutu 
pendidikanya. Salah satu usaha pembenahan yang perlu untuk dilakukan adalah pada manajemen pendidikan Islam. Sebagaimana diungkapkan Mulyasa bahwa hambatan utama dalam pengembangan pendidikan bukan semata-mata pada aspek keuangan, tetapi bertumpu juga pada aspek manajemen (Mulyasa, 2002).

Implementasi manajemen yang efektif dan efisien dalam lingkup Lembaga pendidikan bertujuan untuk meningkatkan kualitas pengelolaan madrasah dengan memberikan keleluasaan dan menumbuhkan partisipasi madrasah dalam upaya perbaikan kerja di madrasah secara kontinu. Sistem pendidikan di Indonesia yang berkaitan dengan manajemen kelembagaan telah diatur dalam berbagai peraturan dan perundang undangan seperti Undang-Undang Sistem Pendidikan Nasional Nomor 20 tahun 2003 dan Peraturan Pemerintah Republik Indonesia Nomor 13 Tahun 2015 sebagai pengganti PP No. 19 tahun 2005 tentang Standar nasional Pendidikan serta Peraturan Pemerintah yang menyertainya (Sagala, 2009).

Dengan demikian, manajemen pendidikan Islam memiliki peran yang sangat penting dalam lembaga pendidikan Islam sebagai upaya peningkatan mutu madrasah yang memicu spirit kreativitas dan inovasi (Rouf, 2017). Manajemen pendidikan Islam merupakan hal yang perlu mendapat perhatian serius dari kepala madrasah. Sebagaimana dikatakan Khozin, salah satu kegagalan dalam pengelolaan madrasah, baik swasta maupun negeri adalah lemahnya pemimpin dalam menjalankan tugas yang diemban (Khozin, 2006).

Tujuan Manajemen pendidikan erat sekali dengan tujuan pendidikan secara umum, karena Manajemen pendidikan pada hakekatnya merupakan alat untuk mencapai tujuan pendidikan secara optimal. Apabila dikaitkan dengan pengertian manajemen pendidikan pada hakekatnya merupakan alat mencapai tujuan. Adapun tujuan pendidikan nasional yaitu untuk mengembangkannya potensi peserta didik agar menjadi manusia yang beriman dan bertaqwa kepada tuhan yang maha esa, berakhlak mulia, sehat, berilmu, cakap, kreatif, mandiri, dan menjadi warga Negara yang demokratis serta bertanggung jawab (UndangUndang Nomor 20 Tahun 2003 Tentang Sistem Pendidikan Nasional, 2003) . Tujuan pokok memperlajari Manajemen pendidikan adalah untuk memperoleh cara, teknik, metode yang sebaik-baiknya dilakukan, sehingga sumber-sumber yang sangat terbatas seperti tenaga, dana, fasilitas, material maupun spiritual guna mencapai tujuan pendidikan secara efektif 
dan efisien.

Dalam proses manajemen terlibat fungsi fungsi pokok yang ditampilkan oleh seorang manajer, yaitu: perencanaan (planning), pengorganisasian (Organizing), Pemimpinan (Leading) dan pengawasan (controlling) (Usman, 2013) Adapun pengertian manajemen dari sudut fungsinya adalah proses, kegiatan merencanakan, pengorganisasian, pengarahan, pelaksanaan, dan pengendalian sumber daya organisasi untuk mencapai tujuan secara efektif dan efisien (Makbuloh, 2011). Sejalan dengan pendapat di atas bahwa fungsi-fungsi manajemen yaitu :

a. Plaining (Perencanaan), bagi setiap manajemen harus mempunyai planning atau perencanaan yang jelas, karena dengan perencanaan merupakan proses awal dalam menentukan tujuan manajemen yang akan dicapai. Dalam banyak hal perencanaan memegang peran strategis karena fungsi-fungsi manajemen lainnya tidak dapat berjalan tanpa perencanaan.

b. Organizing (pengorganisasian), pengorganisasian adalah keseluruhan proses pengelompokan orang-orang, alat-alat, bahan-bahan, tugas, tanggung jawab, wewenang dan fasilitas sehingga tercapai suatu organisasi yang dapat digerakan sebagai suatu kesatuan dalam rangka mencapai tujuan yang telah ditetapkan.

c. Actuating (kegiatan), kegiatan adalah tindakan atau aktivitas seluruh komponen manajemen, bekerja menurut tugas masing-masing, alat-alat dan fasilitas dipergunakan menurut fungsi dan kegunakan masing- masing, dan biaya sesuai dengan alokasi biaya yang dibutuhkan untuk mencapai tujuan manajemen.

d. Controlling (pengawasan), pengawasan atau pengendalian merupakan salah satu fungsi manajemen yang menjamin bahwa kegiatan dapat memeberikan hasil seperti seperti yang diinginkan. Pengawasan diperlukan agar semua kegiatan berjalan sesuai dengan yang diharapkan (Makbuloh, 2011).

Dalam konteks kurikulum 2013, spirit yang dibangun dalam desain manajemen Pendidikan tidak hanya berorientasi pada kualitas kerja Pendidikan an sich, akan tetapi juga mencakup masalah kualitas kehidupan bangsa secara umum. Hal ini berarti, implementasi dari manajemen Pendidikan dapat membawa dampak baik secara internal maupun eksternal madrasah. Dalam mengimplementasikan spirit ini, secara internal, 
semua unsur Pendidikan yang ada dikelola dengan menggunakan kacamata fungsi manajemen, sebagaimana dijelaskan di atas yang implikasinya (baca: asas kebermanfatannya) dapat pula dirasakan masyarakat luas, maka disinilah letak peran penting seorang kepala madrasah dalam menyusun elemen manajamen pendidikan melalui inovasi-inovasi.

Dinamika kebijakan Pendidikan nasional menjadi motivasi dalam melakukan berbagai terobosan dalam bentuk inovasi yang menjadi tuntutan substantif. Inovasi yang membawa spirit pembaharuan, dalam konteks manajemen Pendidikan menjadi tantangan tersendiri dalam mengejawantahkannya. Secara spesifik inovasi mengusung tema perubahan yang baru yang menuju ke arah perbaikan yang lain atau berbeda dari yang ada sebelumnya, yang dilakukan dengan sengaja dan berencana (Idris \& Jamal, 1992).

Menurut Sa'ud inovasi adalah (innovation) ialah suatu ide, barang, kejadian metode yang dirasakan atau diamati sebagai suatu hal yang baru bagi seseorang atau sekelompok orang (masyarakat), baik itu berupa hasil invention maupun diskoveri. Inovasi diadakan untuk mencapai tujuan tertentu atau untuk memecahkan suatu masalah tertentu (Sa'ud, 2009).

Berdasarkan informasi yang didapat berdasarkan hasil observasi dan wawancara dengan kepala sekolah, waka kurikulum dan beberapa guru di sekolah tersebut, bahwa MTs Ar Rosidiyyah Bandung merupkan madrasah yang berkriteria model. Hal ini berarti, madrasah tersebut memiliki beberapa keunggulan dibandingkan dengan madrasah tsnawiyah lainnya. Keunggulan-keunggulan yang dimaksud salah satunya adalah pada aspek manajemen pendidikan yang diselenggarakan di madarasah tersebut, karena sebuah manajemen pendidikan dipengaruhi proses kerja sama yang sistematik, sistemik, dan komprehensif dalam rangka mewujudkan tujuan pendidikan nasional. Dalam konteks Pendidikan nasional, proses kerjasama yang dimaksud adalah sebuah proses yang dibangun dalam kerangka perencanaan, implementasi dan evaluasi dengan dukungan sumber daya manusia dan fasilitas memadai.

Spirit inovasi manajemen Pendidikan di MTs Ar Rosidiyyah Bandung yang telah terbangun dalam kerja tim seluruh elemen terkait, telah mengantarkan madrasah tersebut menjadi madrasah yang memiliki keunggulan di antara madrasah tsanawiyah lainnya yang 
ada di Kota bandung. Berdasarkan survei penulis, kepala madrasah telah melakukan beberapa terobosan dalam upaya mem-back up untuk peningkatan kualitas dengan memperhatikan unsur-unsur manajemen dalam bentuk inovasi. Di antara upaya yang dilakukan adalah menyusun rencana jangka pendek dan menengah dalam konteks rencana strategis dengan melibatkan SDM internal yang merepresentasikan kebutuhan masyarakat Pendidikan di Bandung serta mempertimbangkan kekuatan dan peluang yang dimiliki. Buahnya adalah MTsN Ar Rosidiyyah mendapatkan akreditasi A, yang menjadi simbol kualitasnya. Hal inilah yang menjadi daya Tarik bagi penulis untuk menggali dan menalaah lebih dalam tentang inovasi manajemen di madrasah tersebut.

Berdasarkan alur pemikiran di atas, maka artikel ini akan mengkaji bagaimana inovasi manajemen pendidikan dan bagaimana tahapan-tahapan yang akan dilakukan di MTs Ar Rosidiyyah Bandung sehingga menjadi baik seperti sekarang ini.

\section{METODOLOGI}

Penelitian ini adalah penelitian lapangan (field work research) yang akan menggali tentang inovasi manajemen Pendidikan di MTs Ar Rosidiyyah Bandung yang melingkupi aspek perencanaan, implementasi dan evaluasi. Adapun jenis penulisan ini adalah studi kasus yang dilakukan secara intensif, terperinci, dan mendalam terhadap suatu organisme (individu) lembaga atau gejala tertentu dengan daerah atau subjek yang sempit. Sumber data dalam penulisan ini adalah kepala madrasah, waka sarpras, waka kurikulum dan beberapa guru. Dalam melakukan pengumpulan data, penulis menggunakan tiga macam teknik, yaitu observasi, wawancara dan dokumentasi. Sekanjutnya penulisan ini dianalisis dengan menggunakan model analisis interaktif Milles and Huberman, dengan alur reduksi data, penyusunan data dan penarikan kesimpulan

\section{HASIL DAN PEMBAHASAN}

Inovasi manajemen Pendidikan di MTs Ar Rosidiyyah Bandung merupakan penulisan yang menvoba menggali aspek-aspek manajerial yaitu perencanaan, pelaksanaan dan evaluasi. Pada tiga fungsi manajemen ini selanjutnya penulis akan menggali secara lebih mendalam berkaitan dengan inovasi-inovasi yang dilakukan oleh pihak madrasah. Dalam 
penelitian ini penulis memfokuskan pada manajemen kurikulum dan manajemen kesisiwaan. Hal ini disebabkan karane dua bidang inilah yang menurut hemat penulis banyak melakukan inovasi-inovasi. Berdasarkan hasil temuan yang penulis dapatkan di lapangan, adalah :

\section{Inovasi di Bidang Perencanaan}

Perencanaan (planning) merupakan process of setting objectives and determining what should be done to accomplishment (proses penetapan tujuan dan hal yang sebaiknya dilakukan untuk mencapai tujuan tersebut) (Schermerhorn \& Chappell, 2010). Merencanakan pada dasarnya merupakan proses penentuan kegiatan yang akan dilakukan di masa depan. Kegiatan ini bertujuan untuk mengatur berbagai sumber daya agar hasil yang dicapai sesuai dengan yang diharapkan. Hal ini berarti bahwa dalam proses perencanaan terdapat upaya penggunaan sumber daya manusia (human resources), sumber daya alam (natural resources), dan sumber daya yang lainnya (other resources) untuk mencapai tujuan.

Berdasarkan temuan penulis berkaitan dengan inovasi pada aspek perencanaan, bahwa pendayagunaan sumber daya manusia (human resources), sumber daya alam (natural resources), dan sumber daya yang lainnya (other resources) telah dilakukan secara maksimal. Pada aspek human respourses (dalam hal ini kepala madrasah) telah memilih dan menyusun struktur organisasi madrasah yang mempertimbangkan aspek kualifikasi keilmuan dan keterampilan yang selayaknya dimiliki oleh setiap orang yang menempati jabatan. MTs Ar Rosidiyyah Bandung memiliki empat wakil kepala madrasah yaitu wakil kepala sekolah bidang kurikulum, wakil kepala sekolah bidang kesiswaan, wakil kepala sekolah bidang sarpras, dan wakil kepala sekolah bidang humas.

Beberapa temuan penelitian yang penulis peroleh di lapangan ada hal-hal menarik yang menurut hemat penulis merupakan suatu bentuk inovasi yang dilakukan dalam sebuah manajemen pendidikan berkaitan dengan inovasi di bidang perencanaan. Waka kurikulum misalkan telah melakukan beberapa upaya perubahan atau inovasi yang mengikuti dinamika kebijakan berbasis kurikulum 2013. Penulis melihat Waka kurikulum telah berhasil melakukan sederetan perubahan atau inovasi yang yang didasari oleh hasil identifikasi permasalahan yang dihadapi oleh para guru sebagai contoh dalam 
mengembangkan kompetensi dasar yang menuntut setiap guru untuk bisa mengejawantahkan nilai-nilai pendidikan karakter telah diberikan dalam bentuk pendampingan melalui berbagai macam forum seperti MGMP ataupun KKP ataupun konsultasi secara pribadi sehingga nilai-nilai karakter tersebut dapat terejawantahkan dalam setiap pembelajarannya. Memang dalam pengembangan tersebut dibutuhkan sebuah keahlian bagaimana mengkontekstualisasikan nilai-nilai karakter ke dalam konten pembelajaran misalkan ada dua nilai yang menjadi tuntutan dalam menyusun sebuah Silabus dan RPP yakni karakter religius dan nasionalis.

Menurut hemat penulis berkaitan dengan karakter religius adalah hal yang penting karena substansi dari pendidikan karakter tersebut adalah bersumber dari nilai-nilai ajaran agama maka kemudian internalisasi atau integrasi antara nilai-nilai karakter dengan materi yang akan diajarkan harus tergambar dalam Silabus dan RPP yang mereka susun. Guru dituntut untuk memiliki wawasan keagamaan yang cukup mendalam dan dalam proses penyusunan tersebut Waka kurikulum membangun sebuah komunikasi dengan melibatkan guru-guru lainnya yang terkait utamanya guru PAI dalam memberikan masukan guna mengkontekstualisasikan materi pembelajaran yang dituangkan kedalam Silabus dan RPP tersebut. Begitu pula halnya dengan pengembangan karakter nasionalis yang pada kebijakan kurikulum 2013 sebelumnya belum dicantumkan kemudian pada tahun 2018 karakter nasionalis ini menjadi sebuah instrumen wajib yang harus dilakukan oleh guru dalam pembelajaran di kelas. Dalam diskusi berkaitan dengan pengembangan karakter ini memang awalnya dalam melaksanakan atau mendesain pembelajaran yang di dalamnya terdapat nilai nasionalis sebatas hanya menyanyikan lagu-lagu nasional akan tetapi kemudian hal itu berkembang dengan menggunakan metode seperti yang dilakukan pada pengembangan nilai-nilai religius selain itu juga ditanamkan bahwa dalam teori pembiasaan jika ada suatu hal yang dilakukan secara berulang-ulang maka akan tertanam secara baik dan mendalam dalam memori pikiran siswa Tinggal bagaimana memberikan penguatan terhadap pengetahuan tersebut.

Wakil kepala sekolah bidang kesiswaan juga telah melakukan beberapa perubahan perubahan yang cukup radikal menurut penulis karena dari beberapa prestasi yang diraih serta kegiatan-kegiatan yang berkaitan dengan siswa yang telah didesain sedemikian rupa 
sehingga bisa memberikan kebermanfaatan yang cukup banyak baik pada pribadi siswa maupun dalam mengangkat pamor madrasah. Misalkan dalam menentukan dan memetakan klasifikasi bakat siswa telah dilakukan semacam Penjaringan Bakat sebelum kemudian siswa-siswa tersebut diarahkan untuk mengikuti salah satu atau beberapa bidang pembinaan bakat yang telah disediakan oleh madrasah. Memang ada sebuah keharusan bagi siswa untuk memilih bidang bakat yang cenderung mereka senangi. Hal ini dilakukan agar setiap siswa memiliki sebuah wadah untuk mengasah bakat mereka karena dalam hemat beliau jika hal ini tidak dipaksakan kecenderungan siswa itu malas untuk mengikuti kegiatan- kegiatan tersebut dan hal ini tentunya akan berdampak kurang baik terhadap perkembangan bakat yang dimiliki oleh siswa.

Selain melakukan pembinaan secara intensif terhadap siswa-siswa tersebut, penjaringan bakat ini kemudian dilakukan juga dalam rangka memilih bibit-bibit yang memiliki potensi lebih dominan di antara teman-teman mereka guna dipersiapkan dalam mengikuti berbagai perlombaan Perlombaan yang mewakili madrasah. Dalam hal membina bakat siswa tersebut Waka kurikulum bekerjasama dengan Waka Humas membangun kemitraan dengan lembaga lain ataupun individu profesional yang dianggap memiliki kecakapan untuk memberikan pembinaan kepada siswa. Berdasarkan paparan di atas maka proses inovasi pada tahapan perencanaan dapat kita lihat bahwa ada proses yang dilakukan dalam inovasi perencanaan di MTs Ar Rosidiyyah Bandung diawali dengan menetapkan tujuan yang akan dicapai dalam melakukan perubahan bahwa kegelisahan yang dibangun adalah pembaharuan pembaharuan yang dilakukan merupakan suatu tuntutan dinamis yang mengharuskan sebuah sebuah lembaga untuk menyusun langkahlangkah konkrit dalam melakukan pembaharuan tersebut.

Tentunya tujuan yang dibangun berdasarkan dari identifikasi permasalahan yang yang nampak di permukaan permasalahan yang dimaksudkan di sini adalah ah tuntutan akan sesuatu yang bersifat baru atau update yang menjadi fenomena kekinian dalam masyarakat kemudian beranjak dari identifikasi masalah ini barulah dilakukan sebuah analisis sederhana tentang kekuatan dan kelemahan yang dimiliki oleh pihak Madrasah dalam Menindaklanjuti permasalahan yang dihadapi Sehingga nantinya akan dapat diukur bentuk-bentuk solusi alternatif yang menjadi follow up daripada jawaban terhadap 
permasalahan yang diidentifikasi ketika alternatif masalah tersebut telah dirumuskan maka dibuat pula beberapa alternatif keputusan yang dianggap menjadi win-win solution. Dalam menindaklanjuti bentuk solusi-solusi yang sudah disusun sebelumnya dan perencanaan tersebut tentunya harus senantiasa dievaluasi secara kontinu dan mengukur aspek-aspek mana yang dianggap mungkin harus diperbaharui di kemudian hari. Secara sederhana, proses atau tahapan-tahapan inovasi pada aspek perencanaan dapat penulis gambarkan

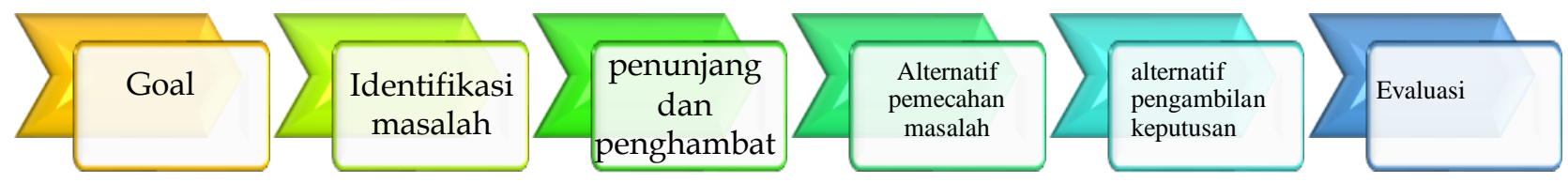
sebagai berikut:

Bagan: Inovasi dalam Perencanaan Manajemen Pendidikan

\section{Inovasi di Bidang Pelaksanaan}

Sebagai tindak lanjut dari sebuah desain perencanaan yang telah disusun sebelumnya tahapanberikutnya adalah mengimplementasikan apa yang sudah direncanakan tersebut. Berdasarkan data yang penulis temukan di lapangan mengimplementasikan perencanaan yang telah disusun MTs Ar Rosidiyyah Bandung menggunakan dua model proses yaitu yang pertama hasil perencanaan tersebut diimplementasikan secara spontan. Dalam prosesnya dalam artian bahwa sering informasi ini dilakukan secara spontan terhadap pihak-pihak yang berkaitan dengan bentuk-bentuk inovasi yang telah direncanakan berkaitan dengan manajemen kurikulum pihak MTs Ar Rosidiyyah Bandung telah membangun kemitraan dengan sekolah-sekolah yang ada di kota Bandung dan beberapa praktisi pendidikan untuk menggodok model-model pengembangan kurikulum berbasis kurikulum 2013.

Bangunan komunikasi dalam bentuk kemitraan ini dilakukan dalam bentuk KKG (Kelompok Kerja Guru) yang dilaksanakan antar guru madrasah atau sekolah Kota Bandung. Selain itu pihak Madrasah juga melakukan pendampingan yang menghadirkan praktisi pendidikan yang dianggap memiliki kemampuan dalam melakukan inovasi di bidang kurikulum. Di bidang kesiswaan pihak Madrasah juga telah melakukan bentukbentuk implementasi inovasi yang di-share kepada beberapa pihak sekolah guna mencari 
respon serta melihat sejauh mana efektivitas dan efisiensi dari pelaksanaan kegiatankegiatan kesiswaan sebagai penunjang pihak madrasah juga menghadirkan tenaga-tenaga profesional yang memiliki keterampilan khusus dalam membina bakat siswa. Bentuk implementasi secara spontan ini, senada dengan bentuk bentuk implementasi inovasi dalam pendidikan sebagaimana yang disebut dengan proses difusi sebagaimana yang dikemukakan oleh Rogers. Difusi ialah proses komunikasi inovasi antara warga masyarakat (anggota sistem sosial), dengan menggunakan saluran tertentu dan dalam waktu tertentu. Komunikasi dalam definisi ini ditekankan dalam arti terjadinya saling tukar informasi (hubungan timbal balik), antar beberapa individu baik secara memusat (konvergen) maupun memencar (divergen) yang berlangsung secara spontan.

Dengan adanya komunikasi ini akan terjadi kesamaan pendapat antar warga masyarakat tentang inovasi. Jadi difusi dapat merupakan salah satu tipe komunikai yakni komunikasi yang mempunyai ciri pokok, pesan yang dikomunikasikan adalah hal yang baru (inovasi). Dalam sistem difusi sentralisasi, penentuan tentang berbagai hal seperti: kapan dimulainya difusi inovasi, dengan saluran apa, siapa yang akan menilai hasilnya, dan sebagainya, dilakukan oleh sekelompok kecil orang tertentu atau pimpinan agen pembaharu. Sedangkan dalam sistem difusi desentralisasi, penentuan itu dilakukan oleh klien (warga masyarakat) bekerja sama dengan beberapa orang yang telah menerima inovasi. Dalam pelaksanaan sistem difusi desentralisasi yang secara ekstrim tidak perlu ada agen pembaharu. Warga masyarakat itu sendiri yang bertanggungjawab terjadinya difusi inovasi.

Bentuk kedua dari inovasi implementasi manajemen pendidikan di MTs Ar Rosidiyyah Bandung yaitu dilakukan secara terencana artinya nya and1 secara spontan menjadi satu bentuk evaluasi untuk memperbaiki teknik dan strategi dalam mengimplementasikan program-program yang telah disusun sistematisasi ini diantaranya dilakukan dalam bentuk menyusun struktur organisasi si dalam kerja dalam mengembangkan kurikulum 2013 yang melibatkan guru guru dan tenaga profesional yang didatangkan dari luar. Hal ini dilakukan dalam rangka memberikan pendampingan intensif sehingga para guru dalam mendesain kurikulum 2013 yang dituangkan dalam silabus dan RPP betul-betul dapat menuangkan ide-idenya sesuai dengan Tingkat kemampuan yang 
dimiliki. Hal ini senada dengan teori yang dikemukakan Rogers yang disebut diseminasi. Diseminasi adalah proses penyebaran inovasi yang direncanakan, diarahkan, dan dikelola. Jadi kalau difusi terjadi secara spontan, maka diseminasi dengan perencanaan. Dalam pengertian ini dapat juga direncanakan terjadinya difusi. Misalnya dalam penyebaran inovasi penggunaan pendekatan ketrampilan proses dalam manajemen Pendidikan di sekolah. Setelah diadakan percobaan ternyata dengan pendekatan keterampilan proses belajar mengajar dapat berlangsung secara efektif dan siswa aktif belajar. Maka hasil percobaan itu perlu didesiminasikan. Untuk menyebarluaskan cara baru tersebut, dengan cara menatar beberapa guru dengan harapan akan terjadi juga difusi inovasi antar guru di sekolah masing-masing. Terjadi saling tukar informasi dan akhirnya terjadi kesamaan pendapat antara guru tentang inovasi tersebut. Thus, dapat dikatakn proses implementasi manajemen Pendidikan menggunakan model difusi dan deseminasi.

Secara sistematis, proses implementasi inovasi manajemen Pendidikan dilakukan pertama melalui sosialisasi kepada pihak internal dan eksternal (terkait). Tahap sosialisasi merupakan tapahan penting mengingat masyarakat Indonesia pada umumnya tidak mudah menerima perubahan, tahap piloting merupakan tahap uji coba agar penerapan inovasi perencanaan tidak mengandung resiko, efektivitas model uji coba memerlukan persyaratan dasar, yiatu akseptabilitas, akuntabilitas, reflikabilitas dan sustainabilitas. Dari bentuk sosialisasi ini kemudian dilakukan proses evaluasi untuk melihak efektivitas dari program-program kerja yang telah direspon oleh pihak-pihak terkait.

Kedua, tahap poling yang merupakan tahap uji-coba agar penerapan dari program kerja yang telah direncanakan tidak mengandung risiko. Efektifitas model uji-coba ini memerlukan persyaratan dasar, yaitu akseptabilitas, akuntabilitas, reflikabilitas, dan sustainabilitas. Akseptabilitas artinya adanya penerimaan dari para tenaga kependidikan, khususnya guru dan kepala sekolah. Akuntabilitas artinya program MBS harus dapat dipertanggungjawabkan, baik secara konsep, operasional, pendanaannya. Reflikabilitas artinya model yang diuji-cobakan dapat direfleksikan di sekolah lain sehingga perlakuan yang diberikan kepada sekolah uji-coba dapat dilaksanakan di sekolah lain. Sustainbilitas artinya program tersebut dapat dijaga kesinambungannya setelah uji coba dilaksanakan.

Ketiga,tahap diseminasi merupakan tahapan memasyarakatkan atau 
merealisasikan program kerja yang telah di uji cobakan ke internal madrasah agar dapat dirasakan kebermanfatannya. Dari diuraian dia atas, berkenaan dengan inovasi dalam implementasi manajemen Pendidikan di MTs Ar Rosidiyyah Bandung, dapat penulis gambarkan pada bagan berikut:

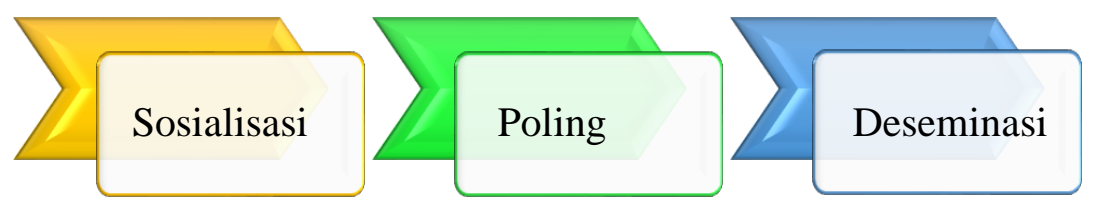

Bagan: Inovasi dalam Implementasi Manajemen Pendidikan

3. Inovasi di Bidang Evaluasi

Setelah tahapan implementasi dilaksanakan dalam sebuah proses manajemen Pendidikan, selanjutnya dilakukan tahapan evaluasi guna mengukur tingkat keberhasilan serta menganalisis factor-faktor yang menjadi kelemahan sekaligus kekuatan pada program kerja tersebut serta melakukan rencana tindak lanjut. Dengan kata lain secara umum evaluasi sebagai suatu tindakan atau proses setidak-tidaknya memiliki tiga macam fungsi pokok, yaitu: mengukur kemajuan, menunjang penyusunan, dan memperbaiki atau melakukan penyempurnaan kembali.

Evaluasi dilakukan diantaranya melihat strategi guru dalam memilih indikator ketika mengembangkan kompetensi dasar dengan mempertimbangkan tiga ranah pembelajaran yaitu kognitif afektif dan psikomotorik termasuk di dalamnya bagaimana keterlibatan guru dalam mendesain kata kerja operasional yang menggunakan prinsip HOTS (Higher Order Thinking Skill). Prinsip HOTS ini bertujuan untuk mengasah daya analisis siswa terhadap semua konsep materi yang dikontekstualisasikan dalam kehidupan nyata kehidupan nyata dalam artian bahwa pengalaman-pengalaman yang ia peroleh di lingkungannya dapat menjadi bahan diskusi untuk mengembangkan konsep atau teori yang didapatkan dari materi pembelajaran. Proses evaluasi yang dilakukan dalam bentuk mengidentifikasi permasalahan-permasalahan yang berkaitan dengan apa yang sudah dituangkan dalam Silabus dan RPP, kemudian membuat skala prioritas sehingga fokus diskusi dapat lebih terarah sesuai dengan permasalahan yang kerap muncul dan dialami oleh para guru. Selanjutnya, hasil identifikasi kemudian dianalisis untuk dicarikan alternatif solusi dalam 
inovasi terhadap konten materi yang akan diajarkan utama yang dituangkan di dalam Silabus dan RPP.

Sedangkan yang berkaitan dengan manajemen kesiswaan bentuk evaluasi yang dilakukan berbeda dengan manajemen kurikulum dalam manajemen kesiswaan bentuk evaluasi yang dilakukan bersifat insidental dan berdasarkan berdasarkan data yang penulis peroleh evaluasi dilakukan satu semester sekali. Hal ini disebabkan karena kesulitan dalam mengumpulkan para Pembina kegiatan kesiswaan yang tidak hanya berasal dari internal Madrasah tetapi juga ada yang berasal dari eksternal madrasah. Akan tetapi berbagai bentuk kegiatan kesiswaan yang diikuti oleh siswa secara tidak langsung menjadi faktor pendukung atau penguat pembelajaran di kelas. Hal ini berarti bahwa ada proses penilaian yang dilakukan bagi siswa setiap dan mengikuti kegiatan-kegiatan yang dia pilih.

Berdasarkan hasil penilaian inilah selanjutnya dilakukan evaluasi tentang tingkat keefektifan kegiatan-kegiatan kesesuaian tersebut. Jika ternyata mayoritas siswa mengalami peningkatan dalam mengikuti kegiatan tersebut maka ini menunjukkan tingkat keberhasilan dan tahapan selanjutnya adalah melakukan pengamatan serta mencari bentuk-bentuk baru dalam teknik pembinaan kegiatan tersebut, akan tetapi jika ternyata kegiatan-kegiatan kesukaan tersebut terlihat menurun dari aspek prestasi yang dicapai siswa maka evaluasi yang dilakukan adalah menjauh ulang kembali layak atau tidaknya kegiatan tersebut untuk terus dilaksanakan.

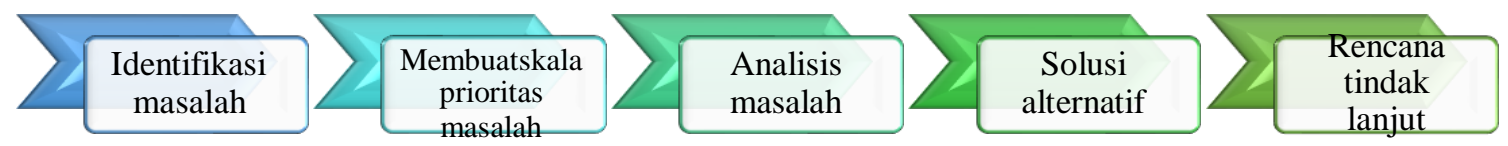

Bagan: Inovasi di Bidang Evaluasi Manajemen Pendidikan

Kondisi yang tergambar di atas secara tidak langsung telah mencerminkan tahapan inovasi yang dilakukan oleh MTs Ar Rosidiyyah Bandung yaitu lahirnya kesadaran (awareness) bersama akan pentingnya melakukan inovasi di bidang kurikulum dan kesiswaan kemudian pihak sekolah dalam hal ini kepala sekolah serta para guru memberikan perhatian (interest) yang besar yang ditandai dengan keterlibatan mereka dalam setiap kegiatan baik yang berkaitan dengan masalah manajemen kurikulum maupun manajemen kesiswaan Selain itu pihak sekolah juga melakukan proses uji coba atau trial berkaitan dengan apa yang telah direncanakan sebelum kegiatan kegiatan tersebut disepakati untuk dilaksanakan. 
Secara keseluruhan hasil dari inovasi manajemen Pendidikan di MTs Ar Rosidiyyah Bandung dapat penulis tuangkan pada table berikut:

\begin{tabular}{|c|c|c|}
\hline $\begin{array}{c}\text { Bidang } \\
\text { Perencanaan }\end{array}$ & $\begin{array}{c}\text { Bidang } \\
\text { Pelaksanaan }\end{array}$ & $\begin{array}{c}\text { Bidang } \\
\text { Evaluasi }\end{array}$ \\
\hline $\begin{array}{l}\text { 1. Goal } \\
\text { 2. Identifikasi masalah } \\
\text { 3. Penunjang dan } \\
\text { penghambat } \\
\text { 4. Alternatif pemecahan } \\
\text { masalah } \\
\text { 5. Alternatif pengambilan } \\
\text { keputusan } \\
\text { 6. Evaluasi }\end{array}$ & $\begin{array}{l}\text { 1. } \text { Sosialisasi } \\
\text { 2. Poling } \\
\text { 3. Deseminasi }\end{array}$ & $\begin{array}{l}\text { 1. Identifikasi masalah } \\
\text { 2. Membuat skala } \\
\text { prioritas masalah } \\
\text { 3. Analisis masalah } \\
\text { 4. Solusi alternatif } \\
\text { 5. Rencana tindak lanjut }\end{array}$ \\
\hline
\end{tabular}

\section{Sumber : MTs Ar Rosidiyyah Bandung}

\section{PENUTUP}

Inovasi manajemen Pendidikan di MTs Ar Rosidiyyah Bandung dilakukan dengan mengacu pada tiga tahapan, yaitu: Pertama, Inovasi pada tahap perencanaan yang di dalamnya mencakup proses goal, identifikasi masalah, penunjang dan penghambat, alternatif pemecahan masalah, alternatif pengambilan keputusan, dan evaluasi.

Kedua, inovasi pada tahap pelaksanaan yang di dalamnya mencakup proses sosialisasi, poling, dan deseminasi.

Ketiga, inovasi pada tahap evaluasi yang di dalamnya mencakup proses identifikasi masalah, membuat skala prioritas masalah, analisis masalah, solusi alternative, dan rencana tindak lanjut

\section{DAFTAR PUSTAKA}

Amiroh, A. H. (2014). Inovasi Pengelolaan Pendidikan. Pemalang Press.

Undang-Undang Nomor 20 Tahun 2003 Tentang Sistem Pendidikan Nasional, (2003).

Idris, Z. H., \& Jamal, L. (1992). Pengantar Pendidikan 1. Gramedia Widiasarana Indonesia.

Khozin. (2006). Manajemen Pemberdayaan Madrasah. UMM.

Makbuloh, D. (2011). Manajemen mutu pendidikan Islam: model pengembangan teori dan aplikasi sistem penjaminan mutu. RajaGrafindo Persada.

Mulyasa, E. (2002). Manajemen Berbasis Sekolah, Bandung, Penerbit PT. Remaja 
Rosdakarya.

Rouf, A. (2017). Transformasi dan Inovasi Manajemen Pendidikan Islam. MANAGERIA: Jurnal Manajemen Pendidikan Islam, 1(2), 333-354.

https:/ / doi.org/10.14421/manageria.2016.12-09

Sa'ud, U. S. (2009). Inovasi Pendidikan. Alfabeta.

Sagala, S. (2009). Kemampuan Profesional Guru dan Tenaga Kependidikan: Pemberdayaan guru, tenaga kependidikan, dan masyarakat dalam manajemen sekolah. Alfabeta.

Schermerhorn, J. R., \& Chappell, D. S. (2010). Introduction to management. John Wiley. Usman, H. (2013). Manajemen: teori, praktik, dan riset pendidikan. Bumi Aksara. 